\title{
Obesity. An analysis of epidemiological and prognostic research
}

\author{
Jana Krzysztoszek ${ }^{1}$, Ewelina Wierzejska², Alicja Zielińska ${ }^{1}$ \\ 1Department of Pharmacoeconomics and Social Pharmacy, Poznan University \\ of Medical Sciences, Poznan, Poland \\ 2Laboratory of International Health, Department of Preventive Medicine, \\ Poznan University of Medical Sciences, Poznan, Poland
}

Submitted: 26 June 2012

Accepted: 21 November 2012

Arch Med Sci 2015; 11, 1: 24-33

DOI: $10.5114 / a 0 m s .2013 .37343$

Copyright $\odot 2015$ Termedia \& Banach

\begin{abstract}
Introduction: Apart from its medical dimension, the current problem with obesity has acquired social urgency. This serious lifestyle disease has a negative impact on a number of life processes in the body, causing distortions and damaging different structures. It also contributes to clinical complications, lowers the quality of life and reduces life expectancy. Apart from health-related consequences, it can bring such unfavourable results as social, mental and emotional disorders.

Material and methods: A systematic review of relevant epidemiological studies on obesity in Poland relative to selected countries in Europe and the world over the past 15 years was conducted. Also an attempt was made at forecasting the development of the obesity problem.

Results: The analysed results demonstrated that the percentage of obese people among the adult population of Poland was on the rise in the period under investigation. Taking into account the estimated growth rate, we can assume that the percentage of obese people in Poland right now might total $23.7 \%$ for men and $23.3 \%$ for women. If no changes are introduced in this respect, in 2020 we can expect a rise to, respectively, $30.3 \%$ and $27.3 \%$, and in 2030 to $37 \%$ for men and $31.4 \%$ for women.

Conclusions: The increase in the percentage of obese people among the adult population in Poland is most likely connected with a positive energy balance. In comparison to other European countries Poland has the highest percentage of obese men and women.
\end{abstract}

Key words: obesity, systematic review, epidemiological research, analysis.

\section{Introduction}

Apart from its medical dimension, the current problem with obesity has acquired social urgency. It is a serious lifestyle disease[1, 2], associated with humiliation, discrimination and stigmatisation, suffering and fear of further degradation [3-6], that is affecting an increasing number of people regardless of age or sex. Initially, it was more prevalent in developed countries, but now it is observed more and more often in developing countries, alongside such problems as hunger and poverty [7].

There are many factors predisposing an individual to an excessive body mass increase: genetic, metabolic [8], neuroendocrinological [9] and also psychosocial [10]. In a vast majority of cases obesity is a consequence of modifications to dietary behaviour in response to environmental and behavioural changes.

\author{
Corresponding author: \\ Jana Krzysztoszek PhD \\ Department \\ of Pharmacoeconomics \\ and Social Pharmacy \\ Poznan University \\ of Medical Sciences \\ 79 Dabrowskiego St \\ 60-529 Poznan, Poland \\ Phone: +4861 8546895 \\ Fax: +48618546894 \\ E-mail: metelska@ump.edu.pl
}


The societal and nutritional changes associated with economic growth, modernization, and globalization of food markets [11-13], industrialization, rapid growth of the service sector and technical/technological development led to a decrease in energy expenditure at work as well as in home and leisure activities [14]. New technologies of food preparation and storage together with home electrification, vacuum cleaners, washing machines and dishwashers help to save time and energy, and also increase the quality of life [14]. On the other hand, the use of these facilities leads to a decrease in physical activity. Lack of physical activity and sedentary lifestyle were shown to lead to overweight and obesity in $15 \mathrm{EU}$ countries [15]. Along with the change in dietary habits - a shift from diets rich in staple complex carbohydrate foods, fruit, vegetables and fish to diets rich in refined carbohydrates, animal fats and vegetable oils, pre-processed and fast foods, confectionery and sweet beverages [14, 16 - they contribute to obesity growth all over the world.

Additionally, the tendencies mentioned can be reinforced by stress and sleep deprivation, as suggested in the research by Epel et al. [17] and Spiegel et al. [18]. They indicate that a high level of stress contributes to an increased intake of food [17]. They also show that a reduction of sleep time from $10 \mathrm{~h}$ to $4 \mathrm{~h}$ a day boosts appetite, especially for highcalorie foods rich in carbohydrates [18].

Another factor which may affect body mass and the amount of adipose tissue is alcohol consumption behaviour. Consumed in excess, alcohol facilitates the development of obesity $[19,20]$.

In the context of obesity, some researchers have also stressed the importance of psychological factors such as certain personality traits, beliefs and expectations of an individual, low self-esteem, a feeling of hopelessness, difficulty in dealing with stress and emotions and a need for consolation [21]. Others highlighted the influence of social and economic factors, e.g. marital status, family situation or relations with friends, and socioeconomic status comprising: employment, education, salaries, poverty, poor housing conditions, and migration status [22].

In conclusion, it should be pointed out that the lifestyle of modern societies is characterized, among other things, by rush, stress, loneliness, inability to spend free time actively, easy access to ever larger portions of commercially marketed food items, inexpensive food sources such as fast foods, increased availability of vending machines with energy-dense items, and decreased physical activity [23], all of which may foster obesity.

The aim of this article is to provide a systematic review of epidemiological research that shows the scale of the problem in Poland relative to selected countries in Europe and the world, to carry out an analysis of changes in obesity prevalence over time and to create a future forecast on the basis of the analysis.

\section{Material and methods}

\section{Search strategy}

A systematic review of the relevant literature devoted to the topic of obesity in Poland was conducted. The search concerned the following databases: MEDLINE, Web of Science, EMBASE, and Polska Bibliografia Lekarska (Polish Doctors' Bibliography). The search words had to be part of the title or abstract. The search terms used were "obesity"/“overweight", "prevalence"/“frequency" and "Poland"/"Polish". Language was restricted to English with the exception of the Polish database search, where Polish language was used. No other limitations were specified. A search on the references cited in review articles was also performed. Other terms related to "obesity" and "overweight", such as weight, excess weight, body size, etc., were not included as keywords. Scanning cross-references and checking review articles minimized the possibility of overlooking relevant epidemiological data. The last search was done on 2 June 2010.

\section{Selection}

The criteria for inclusion of publications in this review were as follows: 1 ) the tested sample had to be representative of the country, i.e. the sample size could not be smaller than $1000(n>1000)$; 2$)$ representativeness was assumed also if the study population had been randomly selected; 3) overweight and obesity were specified using body mass index (BMI); 4) the papers included were published within the space of 15 years (1995-2010).

\section{Validity assessment}

The search resulted in 273 papers. Both the title and the abstract (when available) were examined in all cases. Full text articles were downloaded if their abstracts indicated that they contained epidemiological data on the prevalence of obesity in Poland. In the cases when the abstract suggested that the article may discuss the problem of obesity in Poland or include its epidemiological analysis, the full text was also downloaded. Two researchers assessed the publications independently from one another. To conduct a search as profound as possible, the reference lists of the key articles were also consulted and disagreements discussed.

The next step was the systematic review of the sources of primary research statistics: the resources of the Main Library of the Poznan University of Medical Sciences and publications of the Central Statistical Office. 


\section{Study characteristics}

Our systematic review included both anthropometric and survey studies. Titles and abstracts were checked, then full texts were verified, and finally seven publications were found that met the preestablished criteria. After excluding repetitions, four articles were selected. In addition, four publications of the Central Statistical Office, three titles found in the catalogue of the Main Library of the Poznan University of Medical Sciences and seven further publications discovered while analysing bibliographies of full texts were incorporated.

The collected publications were divided into 2 parts: 1 . studies concerning the adult population and 2. publications on overweight and obesity in children and youth. This review includes only those publications which were related to the adult population, and presents the results of the collected publications whose reliability was verified and which contain current data on obesity in Poland according to sex. The review also included data available

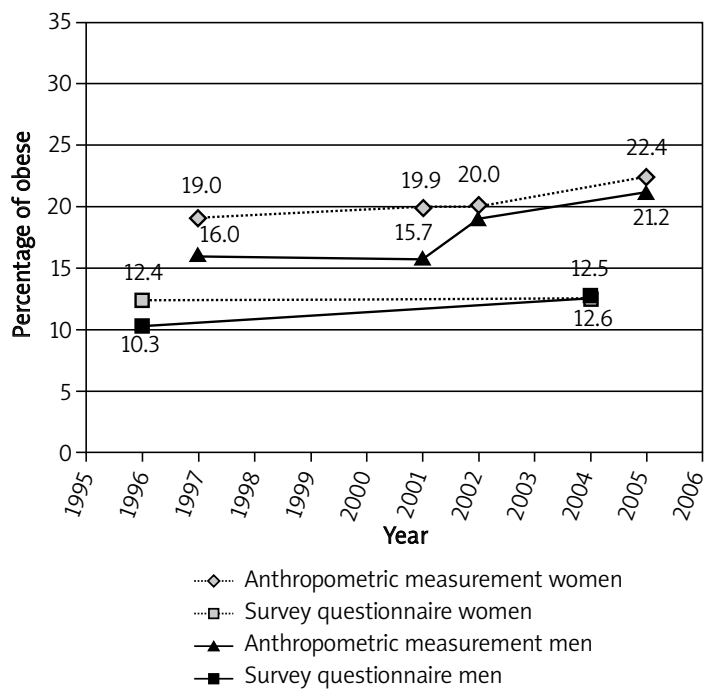

Figure 1. Comparison of the results of national studies on obesity prevalence in women and men in Poland in the years 1996-2005 according to the research method [24-28] from the database of the World Health Organization (WHO Global Infobase).

Next, the analysis of obesity prevalence data was conducted using Microsoft Excel 2010 linear regression (method of least squares) of the data on obesity, which was regarded as the most appropriate and correct method.

\section{Results}

\section{Obesity prevalence in Poland relative to other countries in Europe and the world}

The following results were included in the analysis: NATPOL II [24], NATPOL III [24], Szponar et al. [25] - Household studies of individual food consumption and nutritional status in Poland, WOBASZ Programme [26], CSO of Poland [27, 28] (Table I and Figure 1).

It should be noted that among men aged over 60 a significant fall in the percentage of the obese can be observed (from $25.3 \%$ to $19.3 \%$ ) [25]. This may be caused by a decrease of muscle tissue mass among the elderly that brings about a reduction of the BMI, which does not necessarily reflect changes in the structure of the adipose tissue. It must be mentioned that among women aged over 60 there is a substantial rise in obesity incidence (from $28.8 \%$ to $37.2 \%$ ) [25]. The collected results also point to a very high incidence level for abdominal obesity (waist circumference in women $\geq 88 \mathrm{~cm}$, in men $\geq 102 \mathrm{~cm}$, according to the NCEP-ATP III criteria of 2001 [29]), in particular among women. Abdominal obesity was diagnosed in as many as $40.40 \%$ of women [26]. Severe obesity (BMI $\geq 40$ [30]) also affects mainly women (M-0.60\%, F- 2.2\%) [26].

In order to illustrate the problem of obesity in Poland in relation to other counties in Europe and the world, the data from the WHO database [31] and publications of the CSO [27] were analysed.

The largest percentage of obese people in the analysed period (1995-2005) in European countries can be observed in Germany, the Czech Republic, Portugal and Bulgaria. It must be noted, though, that this rate is on average 3.9\% lower than in Poland. The smallest number of the obese can be

Table I. Results of national studies on obesity prevalence in Poland according to sex in the years 1996-2005 [24-28]

\begin{tabular}{|c|c|c|c|c|c|c|}
\hline \multirow[t]{2}{*}{ Year } & \multirow[t]{2}{*}{ Study } & \multirow[t]{2}{*}{ Research method } & \multirow{2}{*}{$\begin{array}{c}\text { Size of } \\
\text { study } \\
\text { population }\end{array}$} & \multirow{2}{*}{$\begin{array}{l}\text { Age range } \\
\text { [years] }\end{array}$} & \multicolumn{2}{|c|}{ Obesity incidence [\%] } \\
\hline & & & & & Male & Female \\
\hline 1996 & GUS & Survey & 47924 & $\geq 15$ & 10.3 & 12.4 \\
\hline 1997 & NATPOL II & Anthropometric research & 1658 & $18-94$ & 16.0 & 19.0 \\
\hline 2000/2001 & Szponar et al. & $\begin{array}{l}\text { Anthropometric research } \\
\text { and survey }\end{array}$ & 2825 & $\geq 19$ & 15.7 & 19.9 \\
\hline 2002 & NATPOL III & Anthropometric research & 3046 & $18-94$ & 19.0 & 20.0 \\
\hline 2004 & GUS & Survey & 35248 & $\geq 15$ & 12.6 & 12.5 \\
\hline $2003 / 2005$ & WOBASZ & Anthropometric research & 13408 & $20-74$ & 21.2 & 22.4 \\
\hline
\end{tabular}


found in Norway, Sweden and Italy - on average $12.4 \%$ fewer than in Poland.

As for non-European countries, the highest number of obese people can be seen in the USA, Cana$\mathrm{da}$ and Mexico (the percentage of the obese is on average $4.8 \%$ higher than in Poland). On the other hand, the lowest number of obese people has been recorded among the populations of Japan and China; the rate is on average $15.6 \%$ lower than in Poland.

\section{Determining the direction of changes in obesity prevalence in Poland and the world}

The results presented above indicate that in nearly all countries under investigation, including Poland, obesity prevalence increased in the given period. Only among women in Bulgaria and Greece was a downward tendency observed. In European countries, the largest growth of the obese population took place in Germany ( $\mathrm{M}-113.8 \%, \mathrm{~F}-320.8 \%)$, Sweden ( $M-82.5 \%, F-90.0 \%)$, Norway $(M-60.7 \%$, $F-66.0 \%)$ and Portugal ( $M-63.0 \%, F-18.6 \%)$. The smallest growth, apart from the aforementioned decrease in obesity prevalence in Bulgaria and Greece, can be observed in the Czech Republic (M 13.2\%, F- 28.3\%), Austria (M - 26.7\%, F-15.7\%) and Finland (M-46.1\%, F-17.4\%). It cannot be unambiguously stated within which sex group the most radical changes took place, because values for men and women differed greatly across countries. Among the analysed countries, the largest growth of the obese population was recorded in the USA, where it nearly doubled between 1995-2004 ( $M-91 \%$, $\mathrm{F}-98 \%)$. A significant increase was also recorded in Canada (M-67\%, F-79\%).

Using the data presented above, the percentage rates of obese people in selected countries over the analysed time period, relative to sex, were plotted (Figures 2 and 3).

The values of directional coefficient of trend line equations were calculated to determine the directions of changes in obesity incidence. The results are presented in Figures 4 and 5.

Future forecasts are alarming. Assuming that the pace of growth stayed at the estimated levels (analysis on the basis of anthropometric measurement results) for the past 5 years, it can be suspected that the percentage of obese people in Poland at the moment is $23.7 \%$ among men and $23.3 \%$ among women. In 2020, the number of the obese in Poland might reach $30.3 \%$ of the male population and $27.3 \%$ of the female population; in 2030 it may be, respectively, $37.0 \%$ and $31.4 \%$.

The figures above show that the upward tendency is characteristic for all the analysed countries. In some cases, it is even more serious than in Poland. For example, in the U.S. the percentage of obese people at the moment might total $40.8 \%$ among men and $46.9 \%$ among women. As early as

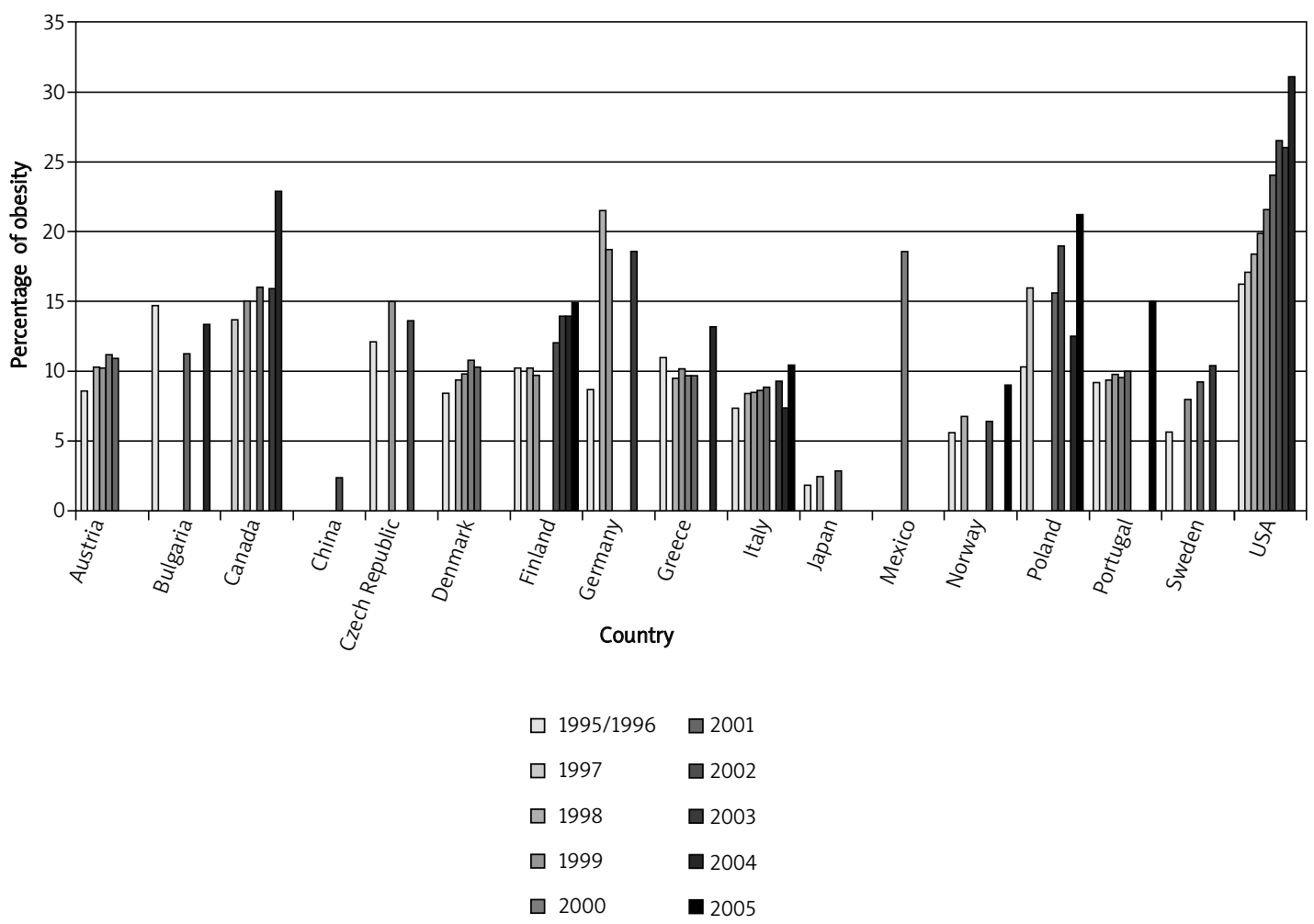

Figure 2. Directions of change in obesity prevalence in men in selected countries of Europe and the world in the years 1995-2005 expressed as a percentage [22-26, 29] 


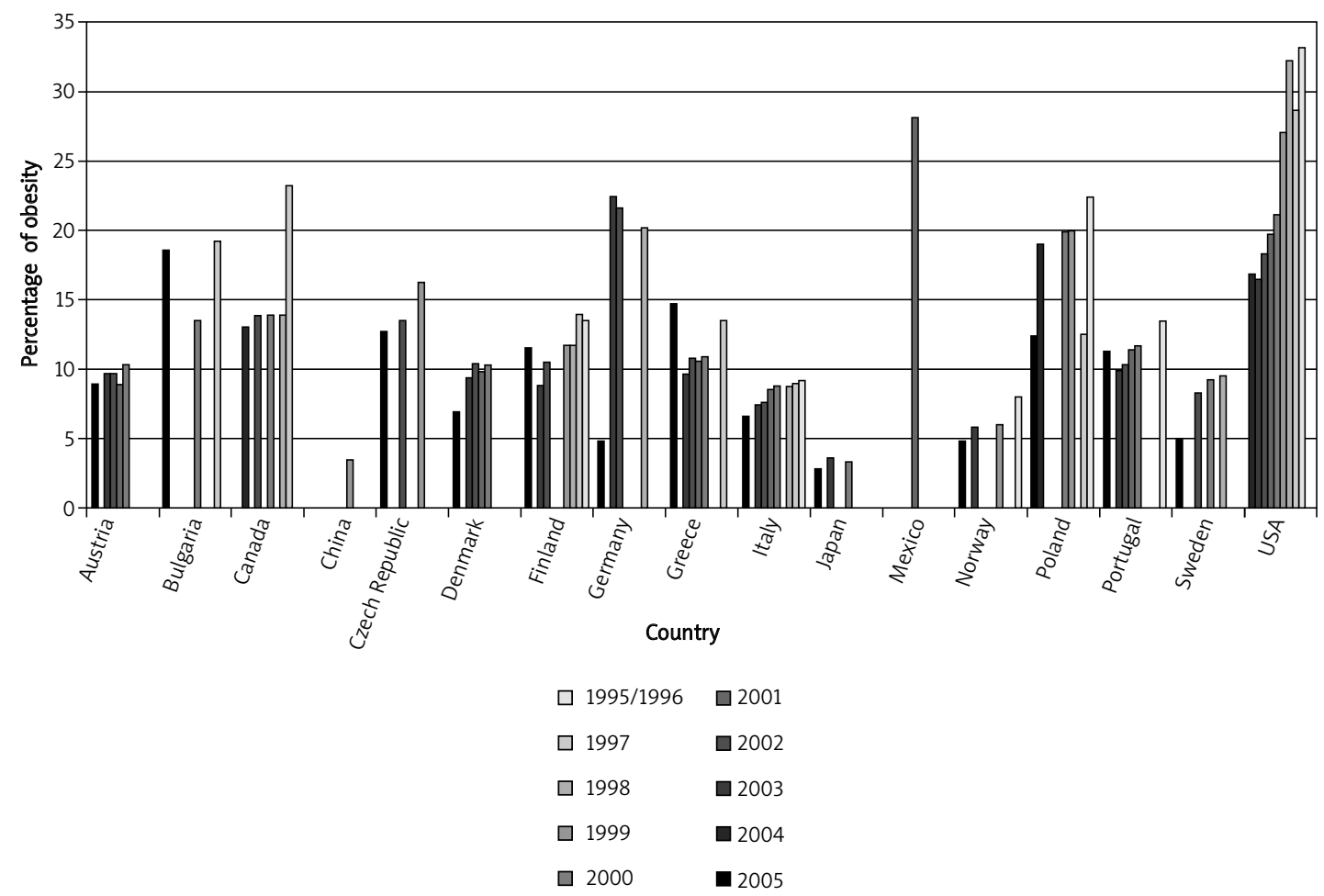

Figure 3. Directions of change in obesity prevalence in women in selected countries of Europe and the world in the years 1995-2005 expressed as a percentage [22-26, 29]

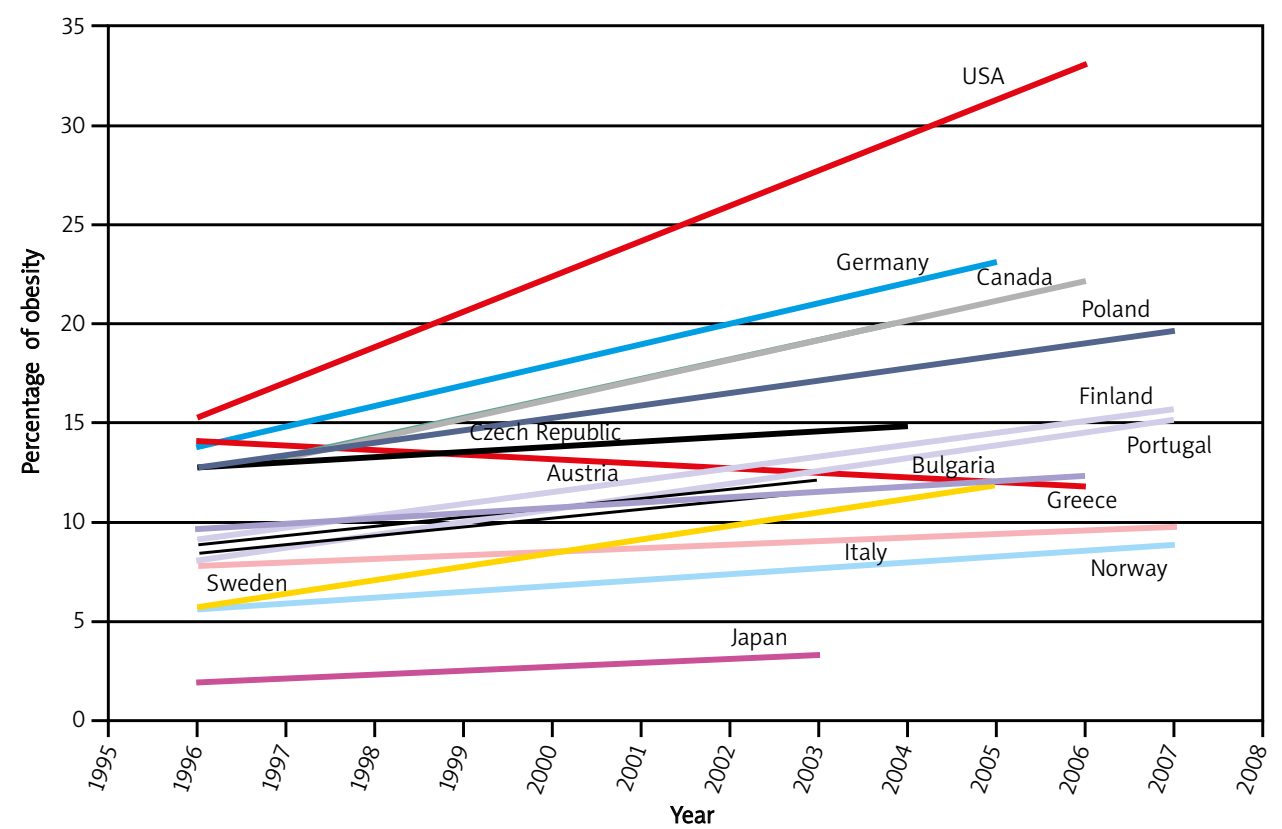

Figure 4. Linear regression lines with a predicted line for men in selected countries of Europe and the world [22-26, 29]

in 2012, a half of adult women may suffer from obesity. Men will reach this value in 2016. With the anticipated growth rate, in 35 years' time obesity might affect almost $100 \%$ of Americans.

\section{Discussion}

During the analysis of the collected material, it was clear to see that the percentage of obese people estimated by the Central Statistical Office on 


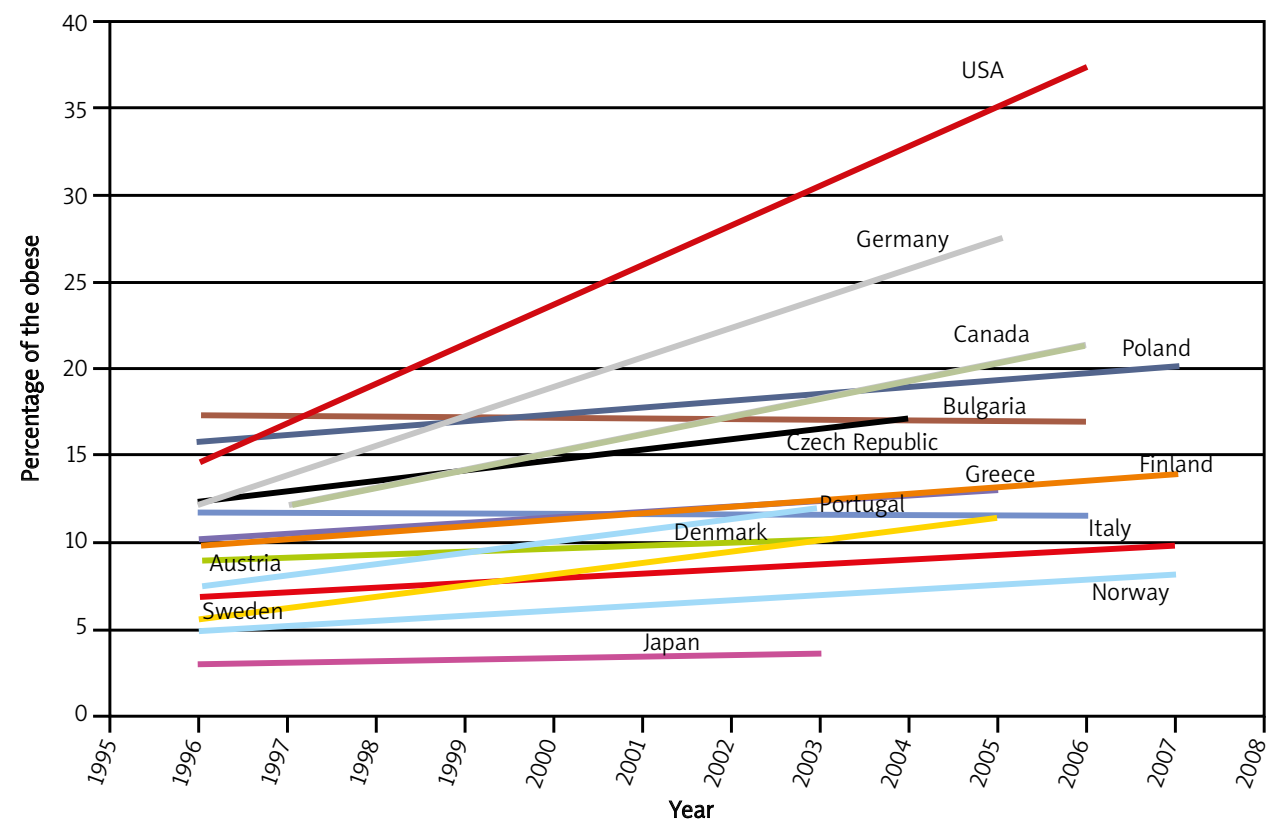

Figure 5. Linear regression lines with a predicted line for women in selected countries of Europe and the world [22-26, 29]

the basis of survey research is much lower than in the research results based on anthropometric measurements. The difference is presumably due to research method issues. It may be indicative of poor health education in the Polish society and, which is closely related, of poor awareness of one's own body mass [32] or, alternatively, a tendency to consciously underestimate one's body mass [33]. In addition, the age range of the research subjects should be noted - it is a little broader than in other studies; apart from adults, the program also included those aged 15-18: a group with a lower percentage of the obese $(1966-0.60 \%$, the remaining age groups $>2.80 \% ; 2004-1.10 \%$, the remaining age groups $>3.60 \%[27,28])$, whereas in other studies the lower age limit was 18 or 19 years. It should also be added that it was only in the CSO study that obesity was defined as $B M I \geq 30.1 \mathrm{~kg} / \mathrm{m}^{2}$, whereas in other studies it was BMI $\geq 30.0 \mathrm{~kg} / \mathrm{m}^{2}$, another factor that might have had an impact on the low-value results.

However, taking into consideration the results of both research methods, it must be said that in the time period under investigation the percentage of the obese among adult residents of Poland rose. Most probably, this is connected with the positive energy balance which results from the excessive consumption of sweetened soft drinks and highly processed foods such as fast foods, irregular meals, snacking between meals, eating in a hurry, small consumption of fruit, vegetables and fish, and too little physical activity [34]. The study on eating habits of Polish adults by Wyka et al. [34] showed an average energy surplus of 800-1200 kcal in food portions daily, which was mainly the result of excessive fat intake (women $-218 \%$, men $-188 \%$ of widely accepted recommendations). It also showed an imbalance between the consumption of vegetable and animal proteins, with a predominance of animal proteins and a very low supply of dietary fibre (about $90 \%$ of accepted recommendations) [34]. Moreover, Gacek et al. [35] reported frequent dietary errors such as irregular meals (50\% of respondents), frequent snacking between meals (about $1 / 3$ of respondents), low consumption of vegetables and fruit (about 2/3 of respondents) as well as fish (about $40 \%$ of respondents), and high consumption of confectionery (about $40 \%$ ).

As far as physical activity is concerned, the results of the 2008 CSO study carried out by means of the questionnaire Special Eurobarometer 183-6/58.2. Physical Activity, 2003 comparing physical activity in Poland to other countries of the old EU (before the accession of 10 countries in May 2004) show that in Poland only $33.5 \%$ of the population exhibit a high level of physical activity [36, 37]. It can be noted that there is no significant difference between Poland and the average for Europe [37, 38].

It also follows from the results presented above that obesity in Poland is more frequent among women than men, which may be caused by the influence of hormones, virilization during menopause and different prevalence rates among women [39].

It must also be stated that the growth dynamics in relation to the percentage of the obese in the population is higher among men. This may indicate 
that this social group is less mindful of their diet, which was presented in the studies of Pawelec [40] and Gacek et al. [35].

The analysis of obesity in Poland in the given period in relation to age demonstrates that it rises significantly with age, which is linked to a reduction of physical activity, a fall in overall energy usage and the consequent redistribution of adipose tissue in the organism [41].

Worth noting is a significant decrease in the percentage of obese over 60 years old (from $25.3 \%$ to $19.3 \%$ ) [25], which may be the result of the attempts to correct previous nutritional errors. The study findings of Gacek et al. [35] are that in all age groups, the group which makes the most rational food choices (the highest average percentage of rational choices: $50.3 \%$ ) is men over 60 years old.

In turn, the increase in obesity prevalence in women over 60 years old (from $28.8 \%$ to $37.2 \%$ ) [25] could be associated with the perimenopausal period when weight gain is observed in $60 \%$ of women with a simultaneous redistribution of body fat especially towards the abdominal area [42].

Analysing the situation in other European countries we discover that the highest percentage of obese people is observed in Germany, Portugal and Bulgaria. Similar observations can be found in Knai et al. [7]. Because the aetiology of obesity is not fully investigated, one of the most probable reasons for such obesity figures in those countries is people's eating habits, associated with the tradition of consuming plentiful, high-calorie meals typical of regional cuisines. Genetic predispositions, low physical activity, faulty eating habits and socio-economic factors are what the researchers consider to be the most probable reasons for the growing problem of obesity in Germany (an increase by 321\% for women and $114 \%$ for men since 1995) [43-46]. Such a significant difference in the increase in prevalence of obesity between sexes suggests that other factors predisposing women to the deposition of body fat such as hormonal changes during pregnancy may also play an important role.

In Poland in the same time period the increase in obesity prevalence was $81 \%$ in women and $106 \%$ in men. A high score in the group of women is also present in Bulgaria, but it should be noted here that the growth rate is much lower than in Germany and Poland (for women - an increase of 3\%, for men a decrease of $9 \%$ ). In Portugal we can observe an increase of obesity prevalence in women (19\%) and men (63\%). The percentage of obese people in these countries, however, is lower compared with the Polish population. Some argue that a reduction in the frequency of physical education classes is a major contributor to obesity [47]. This would also explain the difference. In other countries a higher percentage of individuals with high levels of phys- ical activity is noted; for example, in Germany it is $40.2 \%$, while in Poland, only $33.5 \%[37,48]$. However, Cawley et al. [49] suggest that standard physical education classes have no appreciable impact on obesity levels.

The number of obese residents of Norway, Sweden and Italy is smaller than in Poland by $12.4 \%$ on average of [50]. In these countries there is a habit of eating large amounts of fish, seafood, vegetables and fruit. Additionally, Scandinavian countries are characterized by a low population density and this lack of large population concentrations might support traditional eating habits and reduce the impact of Western culture. It is worth noting that regardless of the relatively low obesity indicators the growth rate of obesity in these countries is high (in comparison to 1995) (in Norway F-67\%, M $61 \%$; in Sweden $\mathrm{F}-90 \%, \mathrm{M}-82 \%$; in Italy $\mathrm{F}-38 \%$ and $M-44 \%$ ) while the percentage of individuals with high levels of physical activity is higher than in Poland (Sweden - 22.9\%, Italy - 25.8\%) [48].

The position of Poland in comparison to countries having the highest percentage of the obese population is not much better; the U.S., Canada and Mexico have on average only $4.8 \%$ more obese people. The situation in the U.S. and Canada is additionally worsened by the intensive growth of obesity rates (U.S.: F - 98\%, M - 91\%; Canada: F $79 \%, M-67 \%)$. The researchers of the obesity problem in the U.S. argue that obesity is more common among persons in their late middle age, women, African Americans, married men and persons with low education and income [51-57]. Among the causes of high obesity prevalence they enumerate: factors connected with lifestyle, which has become more sedentary, with more time spent in front of the computer and TV screens $[55,58,59]$ and acceptance of obesity as a natural state. Americans are eating out more often and becoming accustomed to larger portions [59].

In comparison, in Japan and China the percentage of the obese is on average smaller by $15.6 \%$ than in Poland. The Japanese and the Chinese are far more physically active and their diet is richer in vegetables, fruit, fish and whole-grain products. In these countries being slim is very important. Still, it should be noted that also in these countries the percentage of obese people is increasing [60] (for example in Japan, obesity prevalence growth rates are: $\mathrm{W}-18 \%, M-53 \%)$. Studies of Japanese researchers have not shown significant relationships between weight and low Socioeconomic status in Japan [6164]. Reynolds et al. [65] note that health behaviours are not always better in Japan than in the U.S., but Kadowaki et al. [66] showed in their study that the Japanese are less likely than Americans to be obese. Popkin also draws attention to the trend towards increasing obesity in China, noting also nutritional 
changes. It seems that the shifts in the nature of work and leisure are straightforward, but the changes in diet and the reasons for the structural shifts in diet are what cannot be fully explained [16]. In conclusion, it should be noted that obesity has increased not only in the United States but also it seems to have increased in virtually every country where detailed data are available [67], including Poland. Reasons for this increase are not fully understood [23, 68-70].

Overall, it is clear that there are numerous possible causes of obesity. Consequences of obesity can be grave, both in terms of health and finances. Deterioration of life quality, premature death [71], as well as mental and emotional disorders, are only some of them. Treating this condition is also very expensive [72]. This points to the necessity of introducing a range of actions aimed at preventing the development of obesity, such as nutrition education delivered by health care professionals, educators and organizers of cultural events, awareness campaigns in the media, better nutritional information on food products for conscious choices, creation of places and facilities encouraging physical activity, promoting sport, easier access to institutions that offer nutrition advice and sensitising the public to dangers associated with obesity-related complications.

In conclusion, it must be said that obesity is becoming an increasingly serious problem in many countries [73-77]. In nearly all countries under investigation, the percentage of obese people increased significantly between 1995 and 2005. If this tendency persists, in a few decades the health situation of the population in these countries might be very unfavourable. Therefore, constant monitoring of the socioeconomic patterning of weight is important [78], as are effective obesity prevention programmes.

\section{Conflict of interest}

The authors declare no conflict of interest.

\section{References}

1. Flegal KM, Carroll MD, Kit BK, Ogden CL. Prevalence of obesity and trends in the distribution of body mass index among US adults, 1999-2010. JAMA 2012; 307: 491-7.

2. Januszek-Trzciąkowska A, Małecka-Tendera E, Klimek K, Matusik P. Obesity risk factors in a representative group of Polish prepubertal children. Arch Med Sci 2014; 10: 880-5.

3. Aronne LJ. Obesity as a disease: etiology, treatment, and management considerations for the obese patient. Obes Res 2002; 10, Suppl 2: 95S-6S.

4. Crandall CS. Prejudice against fat people: ideology and self-interest. J Pers Soc Psychol 1994; 66: 882-94.

5. Rand CS, Mcgregor AM. Successful weight loss following obesity surgery and the perceived liability of morbid obesity. Int J Obes 1991; 15: 577-9.

6. Hayden-Wade H, Stein RI, Ghaderi A, Saelens BE, Zabinski MF, Wilfley DE. Prevalence, characteristics, and correlates of teasing experiences among overweight children vs. non-overweight peers. Obes Res 2005; 13: 1381-92.

7. Knai C, Suhrcke M, Lobstein T. Obesity in Eastern Europe: an overview of its health and economic implications. Econ Hum Biol 2007; 5: 392-408.

8. World Health Organization. Obesity: preventing and managing the global epidemic. WHO Technical Report Series 894, Geneva, Switzerland: World Health Organization, 2000.

9. Wyka J, Hirschberg L, Żechałko-Czajkowska A. Nutritional determination of obesity in adults from Wrocław. Rocz Panstw Zakl Hig 2007; 58: 541-8.

10. Wellman NS, Friedberg B. Causes and consequences of adult obesity: health, social and economic impacts in the United States. Asia Pac J Clin Nutr 2002; 11 Suppl 8: S705-9.

11. World Health Organization. Global. Obesity and overweight: fact sheet. Geneva, Switzerland: World Health Organization. Strategy on Diet, Physical Activity, and Health 2003.

12. Hawkes C. Uneven dietary development: linking the policies and processes of globalization with the nutrition transition, obesity and diet-related chronic diseases. Global Health 2006; 28: 4.

13. Hawkes $C$. The role of foreign direct investment in the nutrition transition. Public Health Nutr 2005; 8: 357-65.

14. Popkin BM. The nutrition transition and obesity in the developing world. J Nutr 2001; 131: 871S-3S.

15. Martinez-Gonzalez MA, Martinez JA, Hu FB, Gibney MJ, Kearney J. Physical inactivity, sedentary lifestyle and obesity in the European Union. Int J Obes Relat Metab Disord 1999; 23: 1192-201.

16. Popkin BM. The nutrition transition in low-income countries: an emerging crisis. Nutr Rev 1994; 52: 285-98.

17. Epel E, Lapidus R, McEwen B, Brownell K. Stress may add bite to appetite in women: a laboratory study of stressinduced cortisol and eating behavior. Psychoneuroendocrinology 2001; 26: 37-49.

18. Spiegel K, Tasali E, Penev P, Van Cauter E. Brief communication: Sleep curtailment in healthy young men is associated with decreased leptin levels, elevated ghrelin levels, and increased hunger and appetite. Ann Intern Med 2004; 141: 846-50.

19. Arif A, Rohrer J. Patterns of alcohol drinking and its association with obesity: data from the Third National Health and Nutrition Examination Survey, 1988-1994. BMC Public Health 2005; 5: 126.

20. Schröder H, Morales-Molina JA, Bermejo S, et al. Relationship of abdominal obesity with alcohol consumption at population scale. Eur J Nutr 2007; 46: 369-76.

21. Pietrzykowska E, Wierusz-Wysocka B. Psychological aspects of overweight, obesity and dieting. Pol Merkur Lekarski 2008; 24: 472-6.

22. Ball K, Mishra G, Crawford D. Social factors and obesity: an investigation of the role of health behaviours. Int J Obes Relat Metab Disord 2003; 27: 394-403.

23. McAllister EJ, Dhurandhar NV, Keith SW, et al. Ten putative contributors to the obesity epidemic. Crit Rev Food Sci Nutr 2009; 49: 868-913.

24. Zdrojewski T, Babinska Z, Bandosz P, et al. The relationship between overweight/obesity and elevated blood pressure in representative studies on adult Poles in 1997 and 2002 (NATPOL II, NATPOL III). Medycyna Metaboliczna 2002; 6, supl. 4: 32.

25. Szponar L, Sekuła W, Rychlik E, Ołtarzewski M, Figurska $K$. The studies of individual food consumption and nutritional status of households. IZŻ, Warszawa, 2003. 
26. Biela U, Pajak A, Kaczmarczyk-Chałas K, Głuszek J, Tendera M, Waśkiewicz A. et al. Incidence of overweight and obesity in women and men between the ages of 2074. Results of the WOBASZ program. Kardiol Pol 2005; 63 (6 Suppl 4): S632-5.

27. The health status of the Polish population in 1996. Central Statistical Office, Warsaw 1997.

28. The health status of the Polish population in 2004. Central Statistical Office, Warsaw 2006.

29. Executive Summary of The Third Report of The National Cholesterol Education Program (NCEP) Expert Panel on Detection, Evaluation, And Treatment of High Blood Cholesterol In Adults (Adult Treatment Panel III). JAMA 2001; 19; 2486-97.

30. Obesity: preventing and managing the global epidemic WHO Technical Report Series 894, WHO, Geneva 2000; 9.

31. WHO Global Infobase, www.who.int (20.05.2010).

32. Mastalerz-Migas A, Danecka M, Zywar K, Lubieniecki K, Muszyńska A, Steciwko A. Knowledge of healthy lifestyle in families of children from nursery schools and its practical use. Fam Med Prim Care Rev 2009; 11: 404-6.

33. Gajewska M, Gromulska L. Adolescents' self-reported and measured weight. Pediatr Współcz Gastroenterol Hepatol Żywienie Dziecka 2009; 11: 69-72.

34. Wyka J, Hirschberg L, Żechałko-Czajkowska A. Nutritional determination of obesity in adults from Wrocław. Rocz Panstw Zakl Hig 2007; 58: 541-8.

35. Gacek M, Chrzanowska M, Matusik S. Selected nutritional behaviours of professionally active men in Cracovian population depending on the age. Rocz Panstw Zakl Hig 2007; 58: 549-56.

36. Rzeczpospolita, 13 April 2006.

37. Participation of Poles in sports and active recreation in 2008. Statistical data and publications. Central Statistical Office, Warsaw 2009; 63-80.

38. Sjöström M, Oja P, Hagströmer M, Smith BJ, Bauman A. Health-enhancing physical activity across European Union countries: the Eurobarometer study. J Public Health 2006; 14: 291-300.

39. Tatoń J, Czech A, Bernas M. Obesity. The metabolic syndrome. PZWL, Warsaw 2007.

40. Pawelec M. Feeding preferences of patients of Cardiac Surgery Department of Pomeranin Medical University. Annales UMCS 2005; Suppl. XVI: 255-9.

41. Kotwas M, Mazurek A, Wrońska A, Kmieć Z. Pathogenesis and treatment of obesity in elderly people. Family Medicine Forum 2008; 2: 439.

42. Buksińska-Lisik M, Lisik W, Zaleska T. Obesity - multidisciplinary disorder. Przew Lek 2006; 1: 72-7.

43. Benecke A, Vogel $H$. Übergewicht und Adipositas Gesundheitsberichterstattung des Bundes. Heft 16, Robert Koch-Institut, Berlin 2003.

44. Mensink GB, Lampert T, Bergmann E. Overweight and obesity in Germany 1984-2003. Bundesgesundheitsbl Gesundheitsforsch Gesundheitsschutz 2005; 48: 1348-56.

45. Leyk D, Rüther T, Wunderlich M, et al. Sporting activity, prevalence of overweight, and risk factors: cross-sectional study of more than 12500 participants aged 16 to 25 years. Dtsch Arztebl Int 2008; 105: 793-800.

46. Kuntz B, Lampert T. Socioeconomic factors and obesity. Dtsch Arztebl Int 2010; 107: 517-22.

47. McAllister EJ, Dhurandhar NV, Keith SW, et al. Ten putative contributors to the obesity epidemic. Crit Rev Food Sci Nutr 2009; 49: 868-913.

48. Sjöström M, Oja P, Hagströmer M, Smith BJ, Bauman A. Health-enhancing physical activity across European Union countries: the Eurobarometer study. J Public Health 2006; 14: 291-300.
49. Cawley J, Meyerhoefer C, Newhouse D. The impact of state physical education requirements on youth physical activity and overweight. Health Economics 2007; 16: 1287-301.

50. Ulset E, Undheim R, Malterud K. Has the obesity epidemic reached Norway? Tidsskr Nor Laegeforen 2007; 127: 34-7.

51. Flegal KM, Carroll RJ, Kuczmarski RJ, Johnson CL. Overweight and obesity in the United States: prevalence and trends, 1960-1994. Int J Obes Relat Metab Disord 1998; 22: 39-47.

52. Jeffery RW, French SA, Forster JL, Spry VM. Socioeconomic status differences in health behaviors related to obesity: the Healthy Worker Project. Int J Obes Relat Metab Disord 1991; 15: 689-96.

53. Kaplan GA, Keil JE. Socioeconomic factors and cardiovascular disease: a review of the literature. Circulation 1993; 88: 1973-98.

54. Schoenborn CA. Marital status and health: United States, 1999-2002. Adv Data 2004; 15: 1-32.

55. Smith JP. Healthy bodies and thick wallets: the dual relation between health and economic status. J Econ Perspect 1999; 13: 144-66.

56. Zick CD, Holden K. An assessment of the wealth holdings of recent widows. J Gerontol B Psychol Sci Soc Sci 2000; 55: S90-7.

57. Zhang Q, Wang Y. Trends in the association between obesity and socioeconomic status in U.S. adults: 1971 to 2000. Obes Res 2004; 12: 1622-32.

58. Galuska DA, Serdula M, Pamuk E, Siegel PZ, Byers T. Trends in overweight among US adults from 1987 to 1993: a multistate telephone survey. Am J Public Health 1996; 86: 1729-35.

59. Tanneeru M. Health. Obesity: a looming national threat? CNN 2006.

60. Yoshiike N, Matsumura Y, Zaman MM, Yamaguchi M. Descriptive epidemiology of body mass index in Japanese adults in a representative sample from the National Nutrition Survey 1990-1994. Int J Obes Relat Metab Disord 1998; 22: 684-7.

61. Dorling D. Commentary: the fading of the dream: widening inequalities in life expectancy in America. Int J Epidemiol 2006; 35: 979-80

62. Molarius SA, Seidell JC, Sans S, Tuomilehto J, Kuulasmaa K. Educational level, relative body weight, and changes in their association over 10 years: an international perspective from the WHO MONICA Project. Am J Public Health 2000; 90: 1260-8.

63. Wang Y. Cross-national comparison of childhood obesity: the epidemic and the relationship between obesity and socioeconomic status. Int J Epidemiol 2001; 30: 1129-36.

64. Liu X, Liang J, Muramatsu N, Sugisawa H. Transitions in functional status and active life expectancy among older people in Japan. J Gerontol B Psychol Sci Soc Sci 1995; 50: S383-94.

65. Reynolds SL, Hagedorn A, Yeom J, Saito Y, Yokoyama E, Crimmins EM. A tale of two countries - the United States and Japan: are differences in health due to differences in overweight? J Epidemiol 2008; 18: 280-90.

66. Kadowaki T, Sekikawa A, Murata K, et al. Japanese men have larger areas of visceral adipose tissue than Caucasian men in the same levels of waist circumference in a population-based study. Int J Obes (Lond) 2006; 30 : 1163-5.

67. Caballero B. The global epidemic of obesity: an overview. Epidemiol Rev 2007; 29: 1-5.

68. Keith SW, Redden DT, Katzmarzyk PT, et al. Putative contributors to the secular increase in obesity: exploring the roads less traveled. Int J Obes (Lond) 2006; 30: 1585-94 
69. Astrup AV, Rössner S, Soørensen TI. Alternative causes of obesity. Ugeskr Laeger 2006; 168: 135-7.

70. Bray GA, Champagne CM. Beyond energy balance: there is more to obesity than kilocalories. J Am Diet Assoc 2005; 105 (5 Suppl 1): S17-23.

71. Zhu J, Su X, Li G, Chen J, Tang B, Yang Y. The incidence of acute myocardial infarction in relation to overweight and obesity: a meta-analysis. Arch Med Sci 2014; 10: 855-62.

72. Benecke A, Vogel $H$. Übergewicht und Adipositas Gesundheitsberichterstattung des Bundes. Heft 16, Robert Koch-Institut, Berlin 2003.

73. Tjepkema M, Shields $M$. In: Nutrition: findings from the Canadian Community Health Survey. Issue no. 1. Ottawa, Ontario, Canada: Statistics Canada; Measured obesity: adult obesity in Canada, 2005.

74. Hedley AA, Ogden CL, Johnson CL, Carroll MD, Curtin LR, Flegal KM. Prevalence of overweight and obesity among US children, adolescents, and adults, 1999-2002. JAMA 2004; 291: 2847-50.

75. Dal Grande E, Gill T, Taylor AW, Chittleborough C, Carter P. Obesity in South Australian adults -prevalence, projections and generational assessment over 13 years. Aust N Z J Public Health 2005; 29: 343-8.

76. World Health Organization. Global. Obesity and overweight: fact sheet. Geneva, Switzerland: World Health Organization, Strategy on Diet, Physical Activity, and Health 2003.

77. Rahmanian M, Kelishadi R, Qorbani M, et al. Dual burden of body weight among Iranian children and adolescents in 2003 and 2010: the CASPIAN-III study. Arch Med Sci 2014; 10: 96-103.

78. McLaren L. Socioeconomic status and obesity. Epidemiol Rev 2007; 29: 29-48. 